\title{
PENINGKATAN PENGUASAAN KOSAKATA BAHASA INGGRIS MELALUI PERMAINAN AKADEMI MEMASAK PADA SISWA KELAS $X$ DI SMK NEGERI 1 PANJI SITUBONDO TAHUN PELAJARAN 2019 - 2020
}

\author{
${ }^{1}$ Hari Murdianti, S.Pd, \\ ${ }^{1}$ SMK Negeri 1 Panji Situbondo \\ Email: harimurdianti68@gmail.com
}

Received: Nov 8, $2021 \quad$ Revised: Nov 15, $2021 \quad$ Accepted: Nov 29, 2020

\begin{abstract}
This is a classroom action research aiming at finding out to what extent Cooking Academy, a cooking simulation game created by Fugazo, Inc., enriches vocational students' vocabulary dealing with cooking. I found that the students of Teknologi Pengolahan Hasil Pertanian (TPHP) or Technology of Processing Agriculture Produce class' main problem in mastering and using English was vocabulary. Thus, I expected that Cooking Academy game might enrich their vocabulary. The participants of the research were 32 tenth graders majoring in TPHP of SMK N 1 Panji in the academic year of 2019/2020. The method of collecting data in this research was mixed-method using qualitative data and supported by quantitative data. The participants were given materials dealing with vocabulary used in cooking activities. According to the analyses, the pre-test mean was 42.30 , while the post- test mean was 78.95 . Between pre-test and post-test, they were given two quizzes, quiz 1 and 2 with the mean of 84.84 and 86.09 respectively. The students' participation and attitude during the treatment showed that they appreciated the Cooking Academy game I used in the teaching and learning process.

Based on the results, it could be concluded that there was animprovement of the students' score at $86.6 \%$. So, the Cooking Academy game enriched the vocational students' vocabulary dealing with cooking.
\end{abstract}

Key words: cooking media game, enrichment, vocational students, vocabulary. 


\section{PENDAHULUAN}

Globalisasi saat ini telah melanda dunia dan menyatukan berbagai aspek. Perubahan dan peningkatan sarana informasi dan komunikasi menjadi satu hal yang mendasar. Perkembangan interaksi antar manusia melalui media semakin maju seiring dengan mobilitas dalam ilmu pengetahuan. Dimana dunia pendidikan ikut memberikan kontribusi terbesar bagi kesiapan semua pihak dalam menghadapi globalisasi tersebut.

Pendidikan menurut Ki Hajar Dewantara yaitu tuntunan di dalam hidup tumbuhnya anak - anak. Salah satu aspek yang dikembangkan dalam pendidikan adalah aspek perkembangan bahasa. Aspek tersebut ditujukan agar anak mampu mengungkapkan pikiran melalui bahasa yang sederhana secara tepat, mampu berkomunikasi secara efektif dan membangkitkan minat untuk dapat berbahasa. Seiring dengan berkembangnya zaman, penguasaan bahasa asing menjadi perhatian terbaru untuk perlu diasah kembali. Bahasa yang saat ini dianggap sebagai bahasa yang dapat digunakan secara luas dan efektif adalah Bahasa Inggris.

Untuk bisa berkomunikasi dengan menggunakan Bahasa Inggris secara baik tentunya harus menguasai kosakata yang memadai pula. Penguasaan kosakata Bahasa Inggris tersebut tidak serta merta tumbuh dengan sendirinya dalam diri anak. Pembinaan yang konsisten terealisasikan dalam bentuk belajar dan pembelajaran di sekolah dasar.

Pada umumnya, siswa-siswi yang baru memulai untuk belajar Bahasa Inggris sangat membutuhkan pengetahuan mengenai kosakata karena dengan adanya pengetahuan kosakata yang baik dan memadai, maka siswa akan mampu untuk mengerti maksud dari Bahasa Inggris tersebut.

Kosakata atau dalam bahasa Inggris disebut dengan vocabulary, adalah salah satu komponen penting dalam berbahasa. Dengan menguasai vocabulary secara baik maka seseorang dapat menghubungkan empat keterampilan berbicara, mendengar, membaca dan menulis. Sebagaimana yang dinyatakan oleh Nunan bahwa, "kosa kata adalah bagian penting yang memudahkan dalam menggunakan bahasa kedua, karena tanpa sebuah kosa kata yang benar bahasa tidak akan dapat berfungsi secara struktur dan akan susah 
untuk dipahami." Maka jelaslah bahwa kosakata punya peran penting dalam berbahasa.

Oleh karena itu, dalam penelitian ini, peneliti menggunakan jenis permainan komputer - game Cooking Academy - yang atraktif dan menarik sebagai media untuk belajar kosakata bahasa Inggris, khususnya di bidang memasak.

\section{METODE PENELITIAN}

Jenis Penelitian ini termasuk dalam Penelitian Tindakan Kelas (PTK). Penelitian yang dilakukan bertujuan untuk memecahkan permasalahan, memperbaiki metode pengajaran, memberikan solusi dalam kegagalan belajar, dan mengadakan pembaharuan yang bersifat lebih segar dalam pembelajaran. Penelitan tindakan kelas yang berbentuk kolaborasi ini menempatkan guru sebagai pihak kolaborator yang memandu pelaksanaan pembelajaran sebagaimana telah dirancang oleh peneliti dengan penerapan permainan cooking academy pada siswa kelas X.

Penelitian bertempat di SMK Negeri 1 Panji Situbondo yang meliputi 1 siklus dengan empat fase yang berupa perencanaan, pelaksanaan tindakan, observasi, dan refleksi. Siklus 1 dilaksanakan sebanyak 3 kali pertemuan dengan rincian 2 pertemuan materi, 1 pertemuan pelaksanaan tes/ulangan akhir.

\section{Jenis Data}

Phillips dan Carr (2010:32) menyatakan bahwa "penelitian tindakan sering dikategorikan sebagai metodologi kualitatif, meskipun data kuantitatif dapat dimasukkan. Dalam hal ini, penelitian tindakan seringkali mencampuradukkan metode." Senada dengan teori Phillips dan Carr, Burns (2010: 104) juga berpendapat bahwa sebenarnya, refleksi data peneliti dalam kombinasi (kualitatif dan kuantitatif) dengan melakukan penelitian tindakan sangat penting dalam penelitian tindakan.

\section{Prosedur Pengumpulan data}

Prosedur penelitian ini dijelaskan dalam penjelasan berikut:

\section{Perencanaan}

Dalam perencanaan, isu atau masalah diidentifikasi. Di sini, saya menentukan investigasi apa yang akan digunakan dan perbaikan potensial apa yang akan dicapai. 
Pada tahap pertama penelitian, saya melakukan langkah-langkah berikut:

1) Pertama, saya melakukan studi pendahuluan di SMK N 1 Panji Situbondo untuk mengamati masalah apa yang dihadapi siswa dalam belajar bahasa Inggris,

2) setelah menemukan bahwa kosakata adalah masalah yang paling mereka temui, selanjutnya merancang penelitian selanjutnya,

3) kemudian, saya memutuskan untuk menggunakan game Cooking Academy untuk memperkaya kosakata siswa SMK Negeri 1 Panji Situbondo,

4) dalam penelitian ini, saya melakukan satu siklus.

\section{Implementasi}

Implementasi meliputi melaksanakan rencana dan mengamati hasil dari rencana tersebut. Dalam kurun waktu tertentu, saya mengambil bagian dalam proses belajar mengajar yang sebenarnya untuk menerapkan harapan seperti yang saya rencanakan sebelumnya.

\section{Refleksi}

Menurut pengamatan pada kegiatan pertama dan kedua, saya mengevaluasi dan merefleksikan proses belajar mengajar termasuk perilaku siswa. Tidak ada masalah serius selama kegiatan berlangsung. Karena sebagian besar siswa tidak menemukan kesulitan dalam mempelajari kosakata menggunakan permainan, saya didorong untuk melakukannya penelitian satu siklus. Apalagi hasil dari kedua kuis yang saya berikan kepada siswa itu bagus.

\section{DISKUSI}

\section{Gambaran umum}

Partisipan dalam penelitian ini adalah siswa kelas X SMK N 1 Panji jurusan Teknologi Pengolahan Hasil Pertanian (TPHP) atau Teknologi Pengolahan Hasil Pertanian. Ada 32 siswa yang diajar menggunakan game Cooking Academy sebagai media dalam mempelajari kosakata bahasa Inggris memasak. Metode yang digunakan adalah penelitian tindakan kelas. Hal ini dilakukan untuk memperkaya kosakata siswa SMK yang berhubungan dengan memasak. Dalam penelitian ini hanya ada satu siklus. Penelitian ini dilakukan dalam enam pertemuan yang dibagi menjadi pre-test, kegiatan pertama dan kuis, kegiatan kedua dan kuis, post-test, dan angket. 


\section{Pengayaan Kosakata Siswa}

Tujuan dari pre-test telah dikemukakan pada sesi sebelumnya yaitu untuk melihat seberapa jauh pengetahuan siswa tentang kosakata memasak, sedangkan post-test adalah untuk mengetahui pengetahuan siswa tentang kosakata setelah diberi perlakuan. Berdasarkan analisis pada bagian sebelumnya, saya ingin mengukur apakah ada peningkatan dari pre-test ke post-test untuk mengetahui sejauh mana permainan Cooking Academy memperkaya kosakata siswa SMK yang berhubungan dengan memasak.

Berdasarkan analisis dari hasil pekerjaan siswa, sebelum diberikan perlakuan rata-rata pretes adalah 42,30. Namun, setelah diberi perlakuan oleh game Cooking Academy, rata-rata post-test adalah 78,95. Kosa kata siswa rata-rata meningkat sebesar 36,65 poin.

Saya menghitung persentase peningkatan dari pre-test ke post-test dengan:

Persentase

$$
=78,95-42,3 \times 100 \%
$$

$$
=86,6 \%
$$

Bagan berikut menggambarkan pengayaan kosakata siswa berdasarkan nilai rata-rata siswa dari pre-test dan post-test:

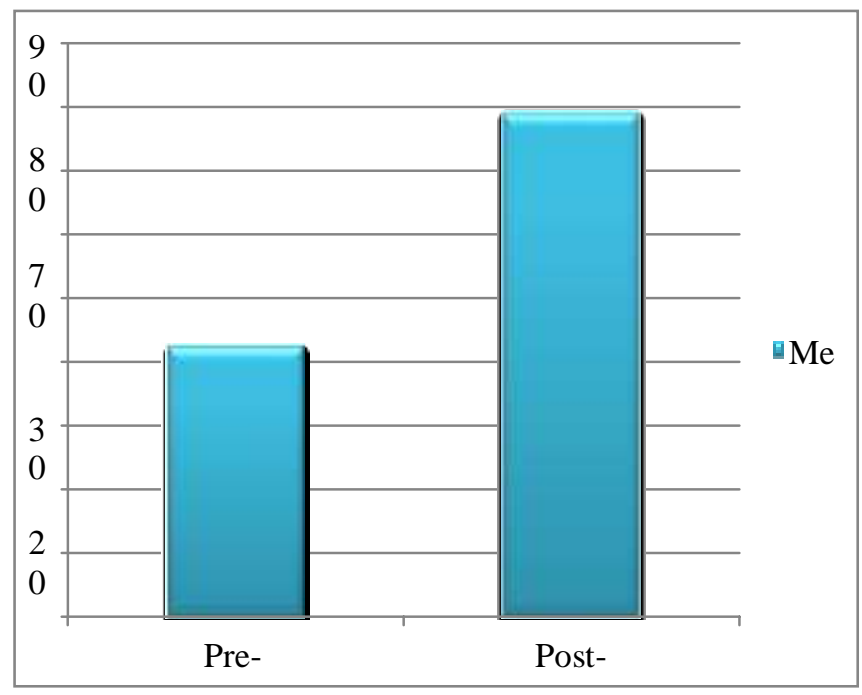

Chart of Mean of Pre-test and Post-test 
Berdasarkan hasil dan grafik, kosakata siswa diperkaya sekitar 86,6\% setelah diberikan perlakuan. Pada pretest, sebelum diberikan treatment, peserta belum mengetahui beberapa kosakata memasak yang disajikan dalam item tes. Namun, setelah disuguhi permainan, pada post-test, para peserta mengenali beberapa kosakata memasak yang sebelumnya tidak mereka ketahui di pretest. Salah satu contoh, sebelum diberikan treatment, hanya dapat menjawab 4 verba dan 7 nomina dengan benar. Kemudian, setelah diberikan treatment, dia bisa menjawab 15 kata kerja dan 13 kata benda. Misalnya, pada pre-test dia tidak bisa menjawab soal tes nomor satu. Namun, di post-test dia menjawab dengan benar, yaitu 'Parut jahe!'.

Selain itu, dalam angket yang saya berikan, semua siswa setuju bahwa perlakuan (permainan Akademi Memasak) memotivasi mereka untuk belajar bahasa Inggris, dan permainan itu memperkenalkan mereka kosakata memasak baru dan membantu mereka mengingatnya.

\section{KESIMPULAN}

Setelah melakukan penelitian, ada dua hal yang dapat diambil sebagai kesimpulan, yaitu:

1) berdasarkan analisis data, saya menemukan bahwa sebelum diberikan perlakuan, rata-rata pre-test adalah 42,30. Namun, setelah diberi perlakuan menggunakan game Cooking Academy, rata-rata post-test adalah 78,95. Hasil penelitian menunjukkan bahwa terdapat peningkatan nilai siswa sebesar $86,6 \%$. Jadi, dapat disimpulkan bahwa ada peningkatan kosakata siswa SMK yang diajarkan menggunakan game Cooking Academy;

2) game Cooking Academy memperkaya kosakata siswa SMK yang berhubungan dengan memasak. Dengan bermain game, siswa dapat memahami dan mengingat kosakata baru dengan mudah. Mereka bisa bermain game sambil belajar kosa kata. Itu membantu, menyenangkan dan menarik. Mereka juga bisa belajar kosakata baru yang dirangsang oleh gambar visual dan bermain memasak menu langkah demi langkah, mengikuti setiap instruksi yang diberikan. 


\section{DAFTAR PUSTAKA}

Burns, A. 2010. Doing Action Research in English Language Teaching (A Guide for Practitioners). New York: Routledge.

Creswell, J. W. 2003. Research Design: Qualitative, Quantitative, and Mixed Methods Approaches ( $2^{\text {nd }}$ edition). United States of America: SAGE Publication.

Ediger, M. 1999. Reading and Vocabulary Development. Journal of Instructional Psychology, 26/1. Page 1-15.

Felder, H. and S. L. Glavin. 1995. Vocational Education: Changes at High School Level after Amendments to Perkins Act. United States: General Accounting Office.

Freire, P. 1983. The Importance the Act of Reading. Journal of Education, 165/1. Page 5-11.

Hiebert, E. H. and M. L. Kamil. 2005. Teaching and Learning Vocabulary.

London: Lawrence Erlbaum Associates, Inc.

Hornby, A. S. 2005. Oxford Advanced Learner's Dictionary ( $7^{\text {th }}$ edition). Oxford: Oxford University Press.

Hyman, C. (ed). 2000. Action Research Guide for Alberta Teachers. Edmonton: Alberta Teachers' Association (ATA).

Jordan, E. 2012. Cognates in Vocabulary Size Testing - a Distorting Influence? Journal of Language Teaching I Asia, 2/3. Page 5-17.

Kurniasih, T. 2008. The Use of "English and Me" Video as a Audiovisual Media for Teaching Vocabulary in the Elementary School (the Case Study of Fourth Grade Students of SD Negeri Randusari, Doro-Pekalongan in the Academic Year of 2007/2008). Final Project of English Department, Semarang State University.

Larsen-Freeman, Diane. 2000. Techniques and Principles in Language Teaching $\left(2^{\text {nd }}\right.$ edition). New York: Oxford University Press.

Manikam, G. H. M. 2009. The Use of Flash Game as a Media to ImproveStudents' Vocabulary (a Case of Year Seventh Students of SMP N 1Kaliwungu. Final Project of English Department, Semarang State University.

McCarthy, M. 2003. Language Teaching: Vocabulary. New York: Oxford University Press. 
McNiff, J. 1997. Action Research: Principles and Practice. New York:Routledge.

Mikulecky, B. S. and L. Jeffries. 2004. More Reading Power ( $2^{\text {nd }}$ edition). New York: Longman.

Mitchell, A. and C. Savill-Smith. 2004. The Use of Computer and Video Gamesfor Learning. London: Learning and Skills Development Agency.

Mujiyanto,Yan. 2011. Petunjuk Penulisan Skripsi. Semarang: Semarang State University Press.

Nunan, D. 2003. Practical English Language Teaching ( $1^{\text {st }}$ edition). New York: McGraw-Hill companies.

Phillips, D. K. and K. Carr. 2010. Becoming a Teacher through Action Research: Process, Context, and Self-study ( $2^{\text {nd }}$ edition). New York: Routledge.

Pikulski, J. J. and S. Templeton. 2004. Current Research: Teaching and Developing Vocabulary: Key to Long-Term Reading Success. U.S.A.: Houghton Mifflin Company.

Ruddell, M. R. 2005. Teaching Content Reading and Writing ( $4^{\text {th }}$ edition). United States of America: John Wiley \& Sons, Inc.

Saputro, N. 2008. The Effectiveness of Using Motion Pictures in VCD "I Can Speak English" as a Media for Teaching Vocabulary at Elementary School (the Case of the Fifth Grader of SDN 1 Pejengkolan Kebumen in the Academic Year of 2007/2008. Final Project of English Department, Semarang State University.

Soehendro, B. 2006. Standar Isi untuk Satuan Pendidikan Dasar dan Menengah. Jakarta: BSNP.

Walter, E. 2008. Cambridge Advance Learners' Dictionary ( $3^{\text {rd }}$ edition). New York: Cambridge University Press.

Wright, A. et al. 1983. Games for Language Learning. New York: Cambridge University Press. 